\title{
HOW DOES MASS IMMIGRATION TRANSFORM THE DESTINATION SOCIETIES?
}

\section{Dilshad SABRI ALI, Msc}

Universit of Soran, Faculty of Arts, dilshad.ali@soc.soran.edu.krd

Article history:
Accepted O1 August 2019
Available online 31 December 2019
Keywords:
Mass immigration
11th September
National identity
Globalization
content analysis

\begin{abstract}
A b s t r a c t
The phenomenon of mass migration is explained thoroughly in this paper. It explains how easy global transportation by air and sea in a technological advanced world has made mass migration much easier. Mass Migration has also been made easier by globalization in that borders and boundaries between countries are being eliminated. Mass migration is explained in the sense that it takes into account the immigrants effect on destination countries such as the European Union, the United States of America, and also Canada. It takes into account how destination countries integrate and absorb these migrants within their economic sectors. It also takes into account how global security has been threatened by mass immigration. This paper also explains how national identity is being maintained in destination countries as mass migration influences the culture and beliefs of a country. The content analysis as methodology was used to discover the issue in this article.
\end{abstract}

\section{Introduction}

Over the last few decades mass immigration has become a reality for large parts of the world, particularly in western developed societies. It is argued that mass immigration has created several advantages for host nations. However, at the same time it has also brought considerable difficulties for destination societies. The concept of international migration is defined by the United Nations, "As a person who stays outside their usual country of residence for at least one year, which is called an international migrant" (Koser, 2007: 4). This definition of international migration will be used as the main point in this article for discussing mass immigration. According to this definition the number of migrations, particularly international migration has increased worldwide, especially in industrialized countries during the second half of the 20th Century. It is expected that by 2050 the number of immigrants who live in the western world will increase by approximately 30\% (Ivlevs and King, 2012: 118).

The number of people who live in another country in 2005 was estimated to be 200 million, which at the time was approximately $3 \%$ of the world's population. This is despite increased attempts by several developed countries to restrict immigration in their societies. This is virtually equivalent to the fifth most populous country in the world, Brazil. In addition, if this rate of immigration is compared to 1960 , it has increased by over twice the amount (Polgreen and Simpson, 2011: 819; Koser, 2007: 4). Recently, the voices of several critics of mass immigration can be heard in a number of destination societies. These critics claim that international migration causes several disadvantages for destination societies, for instance, economic recession, unemployment, pressure on health care and the benefits system, and questions with regards to national identity are some of the issues raised.

In this essay, the role of globalization in the process of migration in industrialized countries in recent decades will be pointed out. In addition, it will briefly look into the history of migration in western developed societies. Further to this, the main objective of the article is to show how mass immigration can transform destination countries. This will be the core part of the essay. The various debates about mass immigration in destination societies will be explored and evaluated.

There are many arguments that illustrate which globalization plays a significant role in increasing the number of international immigrants across the world. Many social scientists, principally sociologists emphasize the connection between globalization and an increasing international migration to developed societies in 
recent decades. People can move from one country to another more readily than in the past because of well-developed transportation systems, relatively safer and inexpensive travel and improved communication technologies such as the internet and mobile telecommunications (Doyle, 2004: 1). Supporters of the migration claim that the world has become a global village and that globalization is a way to accelerate integration and interconnectedness in all dimensions of contemporary social life such as the economy, cultures, national identities and security (Held et al., 1999:2; Heywood, 2011: 11).

\section{Methodology}

This research utilized content analysis in qualitative research to illustrate the range of meanings of phenomena mass migration. The flexibility of utilizing deductive or inductive procedures or a mixture of both approaches in data analysis which is a characteristic of qualitative content analysis. Qualitative content analysis allows researchers to interpretation of texts and documents to understand social reality in a subjective, yet scientific way. In another word, the content analysis of qualitative method depends on interpretation and reading texts by researchers (Bryman, 2012: 289).

\section{A Literature Review of the History of Migration}

There are different views, which might be utilized to consider international migration. Migration has long and important place in history for humankind. It is impossible to illustrate the whole history of international migration in this essay. The history of migration began around 5000BC, when some people separated from the African continent into European countries, and then into other continents (Koser, 2007: 1). In the eighteenth and nineteenth centuries, approximately 12 million people migrated from poorer African countries through slavery to western industrialized societies. Subsequently, a period of increased international migration occurred after World War II. The western developed societies needed to maintain economic growth after the War, as a result, large numbers of North Africans immigrated to Belgium, France, and Turkish workers were employed in Germany.

Most recently in the 1970s and 1990s international migrants increased in industrialized societies such as European countries and the USA (Koser, 2007). As mentioned above, globalization has played a considerable role in increasing the number of migrants around the world, especially in western developed states after the Second World War (Castles and Miller, 2009). For example, reports illustrate that at the beginning of this millennium the figures for international migration were increasing and becoming a complication for destination societies. It was stated that approximately 1 in 4 inhabitants in western developed countries such as the USA, Switzerland, Australia, Germany, Sweden, Canada and New Zealand were foreign born. The great number and various origins of international migrants remarkably challenge long held concepts of citizenship within nation-state boundaries (Bloemraad, et al., 2008: 154).

This increase is not restricted to countries such as Australia, the USA or Canada, which are called the 'classic immigration states'. For instance, in western states the ratio of foreign populations is expected to increase to $30 \%$ by 2050 . Thus, it could be argued that such a rapid increase in population may create sizable ethnic minority groups, who remain isolated from their host nations, causing both negative and positive emotions. The negative emotions may emerge because immigrants sometimes create exploitable social instability as they clash with traditional social structures, notions of nationhood, and culture. The positive emotions that appear might be due to immigrants integrating into the employment sector, economic progress and international cooperation (Ivlevs and King, 2012: 118). Consequently, mass migration has been considered and studied by social scientists, especially sociologists in destination societies from a socioeconomic and social-cultural concept. In addition, international migration has become a considerable issue for destination societies as a threat to security, national identity, especially after the horrific events of 9/11 in New York and 7/7 London (Tanrisever, 2007:238; Ceccorulli, 2009: 10).

Some opponents of migration argue that the problems such as economic recession, security and fading national identity are related to and frequently caused by immigrants in destination countries. Whilst, advocates of migration refute these arguments and claim that migration has more benefits than detrimental effects on the host countries.

\section{The economy and Labor Market}

The concerns with respect to the effects of mass immigration on destination societies are one of the most significant contemporary debates. The number of immigrants who are living in developed societies are increasing and at the same time that several of these countries are encountering enormous structural shifts in their labour markets and economies (Koser, 2007: 90). It is impossible to ignore the role that globalization is having on developed societies. The changing dimensions in these destination societies, it is argued has negative effects from the perspective of proponents of anti-migration and cultural diversity. From the perspective of advocates of immigration, migration has positive impacts on destination countries by bringing a varied and skilled work force, hard working employees, the opportunity to learn 
about and experience diverse cultures for the host nations, and furthermore, some people state they bring a return to traditional family values that developed countries are gradually losing.

A significant focus for debate in destination societies on mass immigration has recently been the labour market and economy. According to economic theory, migrants decide to migrate having compared their situation in their homeland to life in more developed countries (Sjaatad, 1962 cited in Polgreen and Simpson, 2011: 820). If the destination country's conditions, especially economic conditions are better than the person's place of origin, then individuals will decide to move to a host country (Ibid). The main factors in increasing numbers in international migration are the economic issues and economic growth in developed countries. However, these days developed countries are placing more restrictions on the free movement of people, especially immigration from parts of the world such as Africa, Asia and the Sub-continent. This is due to increased unrest from some of their citizens to what they see as 'foreigners' taking jobs, housing, benefit, and gaining free access to health care.

According to standard economic theory, free movement of immigration across borders demonstrates limited evidence of the advantages of immigration due to the economic expense, and the effects of immigrants on welfare and social costs, whilst paying fewer taxes (Orcalli, 2007: 1). Opponents of migration argue that immigration has a remarkable negative influence on labour markets in destination countries. According to Schmidt et al. (1994) immigrants would compete with unskilled domestic labour, in order to obtain the restricted number of occupations, which are available. This causes a decrease in the wages of unskilled workers and can increase social turmoil and raise hostility in destination societies. Schmidt et al., asserts that immigration may threaten the economy, the system of unemployment insurance and the welfare system, which is provided in developed countries (1994: 186).

In contrast, Hijzen and Wright (2010) both illustrate that a rise in the rate of unskilled immigrants has a very small negative effect on unskilled domestic employees wages, and that there is even no notable effect on skilled domestic workers (Hijzen and Wright, 2010:1192). Furthermore, there is a global agreement amongst economists, in extensive terms, which states that the economic effect of immigrants on a destination society is affirmative (Steiner, 2009: 43).

Recently, the economic increase in several developed countries has been related to the positive effect of mass migration. For example, around a quarter percent of labourers in the USA are immigrants. According to the president's Council of Economic
Advisers, "On average, U.S. natives benefit from immigration. Immigrants tend to complement (not substitute for) natives, raising natives' productivity and income. Careful studies of the long-run fiscal effects of immigration concluded that it is likely to have a modest, positive influence". An example of the positive benefits can be seen in the remarkable growth of Singapore's economy in recent decades because of immigrant labourers. Immigrant workers make up one of third Singapore's population (Steiner, 2009: 43). The increase in the economy in both the US and Singapore is a positive example of immigration for proimmigration supporters to critics of mass immigration.

Despite both these positive examples about immigrants in the USA and Singapore, the indigenous people might not like to live with migrants in a society, particularly when they realize their job opportunities are being negatively impacted upon (Damelang and Haas, 2012: 367). Whilst, supporters of immigration claim that if immigrants have negative effects on societies, then why do developed countries receive these migrants? As Steiner (2009) highlighted, Canada attempted to attract high-skilled workers into its labour market, and roughly $59 \%$ of the immigrants were from a high-skilled and business background (Steiner, 2009: 14).

These types of immigrants can contribute to economic growth and investment in developed societies. Critics claim that the large numbers of people who immigrate to developed countries are unskilled and from poor societies such as Asia and Africa. These critics demand that authorities should control borders, in order to decrease the number of immigrants and increase domestic employment (Basu, 2009: 878). Supporters of immigration in destination societies refer to an example of those who claim that most immigrants are unskilled, cause unemployment to rise, and place pressure on the economy.

According to the USA's census report in 1990, around 63\% of people who immigrated to the USA had the minimum of a high school degree. Moreover, approximately $21 \%$ of all migrants had a college or a further degree (Papademetriou, 1997: 20). As Altschuler (2013) emphasized in her article, migration can be positive for host societies due to its highly professional background, which can complement local people in all sectors of society (2013: 549). For example, according to a research in 2008, in the USA, the rate of patents designed by immigrants is actually higher than the indigenous population. These patents produce benefits because of the higher average share of different degrees among skilled immigrants (Niebuhr, 2010: 564). However, antiimmigration proponents argue that enabling a large number of immigrants of different skills, especially the highly-skilled to enter into industrialized societies leads to a rise in negative influences on the high-skilled residents in all sectors. For 
instance, a report by the OECD 2007 Illustrates that $11 \%$ of nurses and 18\% doctors employed in OECD countries were foreign born around 2000 (Castles and Miller, 2009: 64).

This is an example, which can be used to illustrate that immigrants have a negative impact and are likely to take jobs from the local population. As opponents of immigration claim that migrants gradually take hold of all sectors, especially the economic and labour markets in destination countries. Whilst, others claim that immigrants can share their knowledge with native residents, create new opportunities for work and intellectual property, and boost the economy in host countries (Steiner, 2009:44).

\section{Security and Mass Immigration}

Globalization has had an extremely important role in introducing different people and cultures to each other across the world. It can be argued that gathering them together in places creates cultural diversity in destination communities. It can also be debated that globalization has had some negative influences on western societies such as contributing to conflict between majority and minority groups, in terms of religion and security.

There have been millions of immigrants from Asia, Latin America and Africa into destination societies in the more developed western world, and this can bring a lack of integration into these societies, especially after the well-known terrorist attack on the twin towers in New York in 2001 and also the London bombings in 2005 (Castles and Miller, 2009: 3). There are several arguments that countries have rights of control to prevent immigrants from crossing their borders because of the threat to public security, rising crime and terrorism, and social disorder (Seglow, 2005: 319).

Recently, mass immigration and security have become the top place on the policy agenda in destination societies especially in the western world. The critic's voice against migration is increasing. They are demanding governments' change the migration policy because immigrants are a threat to public security and stability in society (Ceccorulli, 2009: 1).

It can be noted that politicians and the media play contribute in spreading xenophobia in western communities and claim that migrants are associated with terrorist groups from outside countries such as the Al-Qaeda. This was due to reports, which documented that a number of immigrants who support Islamic extremism were found to have had links with terrorist groups in Afghanistan and Pakistan (Castles \& Miller, 2009: 4).
After the attacks of women during the 11th September in 2001 and the 7th of July 2005 several reports were published of attacks and harassment of minority groups of people who had migrated to western industrialized countries, particularly Muslim immigrants. In this case, when the immigrants or minority people found themselves the victims of hostility and suspicion, it was an influential factor in encouraging some individuals and groups to take revenge on people in the host societies (Modood and Ahmad, 2007: 188). For instance, this comes from anxiety about terrorist groups and networks attracting alienated young immigrants in host countries to become involved in battles outside the country and act like a 'fifth column' at home (Modood and Ahmad, 2007: 188).

These arguments by anti-migration followers lead to a spread in xenophobia and hostility between migrants and domestic residents in destination communities (Koser, 2007: 61). For instance, it can be mentioned that the riots in May 2001 by Pakistani and Bangladeshi youths against the white youths was due to inequality and hostility as protesters claimed in the UK, which caused chaos, instability in three cities in northern England. This example supports the claim of anti-immigration adherents, in relation to public security disorder in host countries (Vertovec and Wessendorf, 2010: 5). A further instance was that the bulk of participants in the riots, which happened in France, in 2005, were young people who were from a migrant background. Those young French protesters of an African and North African background expressed anger against the high levels of discrimination and hostility from both the indigenous people and the police (Castles and Miller, 2009: 1). These examples encourage anti-migration supporters to pressure their governments to change the migration policy and control the borders, in order to protect security. Furthermore, critics of immigration and racism in western democratic countries claim that each society and culture requires its own mother country, where the native population can live undisturbed others. Commonly, advocates of this viewpoint assert that, like some western people, immigrants can be happier in their homelands and in their natural surroundings as well (Lentin, 2005: 390).

In contrast, these claims that are against mass immigration and cultural diversity from the supporters of immigration and multiculturalism assert that mass immigration has more advantages for destination communities than negative impacts. As mentioned before, there are a few positive effects of migration in the economic section, for example, "the theories of multiculturalism consequently call for recognition and accommodation of cultural minorities, including immigrants, and require states to create policies or laws that allow minority groups to root their 
participation in society within their cultural communities" (Bloemraad et al., 2008: 160).

Contrary to the public debate with respect to immigration in most developed countries which claims that immigration is out of control, supporters of immigration revealed this example from the 1990s, where 7 out of 8 immigrants who settled in developed societies, crossed through regulated borders or channels, which serve the needs of the developed countries much more than the immigrants themselves (Papademetriou, 1997: 16).

\subsection{National Identity and Mass Immigration}

Another point in this article on mass immigration is related to nationality. In the west, destination societies are encountering a disappearance in their own national identity. Immigrants who live in destination countries might have a lower standard of life, such as class, language, education, which leads to them separating themselves from the host communities and a denial of integration with the mainstream nationality and society. These points inevitably lead western host countries and their governments to change their migration policies to try and encourage more integration. The integration requirements are based on knowledge of the host society's culture, history, constitution, language and citizen test (Acosta, 2010: 234). In addition, as Kymlicka (2010) indicates in his book, opponents of mass immigration worry about these factors, highlighted above, as they lead to the weakening of nationality, identity and culture, and also destroy the structure of society in the host countries (Kymlicka, 2010).

It can be pointed out that critics of mass immigration in destination countries claim that foreign people who live in their countries come from different societies with different nationalities, cultures and languages, and appear different in their physical appearance such as clothing, hairstyle and so on. These acts and behaviours from immigrants cause xenophobia to spread among domestic people and lead to problems with the future of national identity and coherence in host societies, especially when immigrants attempt to create a community in which members do not try to integrate into mainstream society, have not loyalty to the host nation and deny learning the language and culture (Castle\& Miller, 2009: 14).

Some politicians and the media have a long history of hostility with mass immigrants. They voice anti- migration concerns and encourage western developed governments to change the policy of migration by showing negative aspects about immigrants, in order to maintain the white identity in western countries, e.g. Critics of immigration argue that immigrants live in white neighborhoods and have the same right as white people, but that they do not have loyalty towards national identity, and deny integrating into mainstream society. For example, in the last few years, the French Parliament voted in favour of a new law, in order to prevent schoolgirls wearing the veil in schools (Vertovec and Wessendorf, 2010:5). This example highlights where destination countries attempt to prevent immigrants keeping their national identity and indicates to them to integrate into mainstream society. On the contrary, the United Nations General Assembly via the approval of the statement of the rights of native people in 2007 stated that "the trend towards enhanced land rights, self-government powers and customary law for indigenous peoples remains fully in place across the Western democracy" (Kymlicka, 2010: 40).

Nevertheless, most western countries in recent years have attempted to change migration policies and add tough questions into migration tests, as illustrated above, for new migrants who want to enter these countries (e.g. Germany, Austria, the UK, Holland and Denmark) (Vertovec and Wessendorf, 2010: 17). In contrast to critics of immigration, who claim that immigrants in destination countries destroy their new countries' identity and social order, several supporters of immigration theories assert that a community's culture and nationality will be richer because of immigrants from different nationalities and cultures (McKinstry, 2013).

If we look at some recent surveys amongst immigrants and domestic people about belonging to the host national identity, we can observe that some immigrants answer that they have strong feelings about the host's national identity. The UK can be seen as an example here because of the large number of immigrants. A survey conducted in 2003 by the 'Home Office Citizenship Survey' among Indians, Pakistanis and Bangladeshis, and white people,asked, 'How strongly do you belong to Britain?' As a result, approximately $86 \%$ of participants answered that they felt strong about belonging to Britain. At the same time, around $86.7 \%$ of white participants answered the same (Kymlika, 2011: 283). This survey highlights mass immigration does not have significant negative impact on destination countries.

\section{Conclusions}

This article has attempted to illustrate the role of mass immigration in altering destination societies, which are chosen by migrants as host countries to live in. In addition, after the Second World War globalization had a strong role in accelerating this process and transforming destination societies in terms of socioculture and socioeconomic -economic through mass immigration. In this essay, I have endeavored to show some arguments about the effects of mass immigration in destination societies, particularly in developed western countries. The article has tried to focus on the labour markets and the economy, which opponents 
of immigration believe have negative impacts on host countries by showing some strong examples. On the other hand, advocates of immigration and cultural diversity disprove these arguments by illustrating positive evidence and claim that immigration has a remarkable effect on destination societies by creating new job opportunities, increasing host countries' economy through investment and sharing their knowledge with domestic laborers. It can be said that the arguments for immigration, which related to the endangerment of public security, and fading national identity and citizenship in destination countries, mainly in developed societies have risen after the attack on the twin towers in New York in 2001 and the London bombings in 2005. Particularly these events lead to the opponent's orientation in relation to immigration turning towards negative changes in destination societies. They support their claims by giving some examples of the negative effects on destination countries of immigration such as a rise in unemployment, culture diversity and national identity. These criticisms lead governments to review some laws on migration to reduce these negative impacts.

In contrast, supporters of mass immigration in destination countries, ask that the western world should not change their laws and policy of migration to tighten levels, in order to limit free movement across borders, especially for immigrants. Furthermore, regulations that lead to immigrants being integrated into mainstream society by force, as illustrated in this essay, the most obvious being in France, should not be allowed.

\section{References}

1. Altschuler, J., (2013), "Migration, illness and health care" Contemporary Family Therapy, Vol. 35, No. 3 pg 546-556.

2. Aosta, D., (2010), "A belief in the purity of the nation: the possible dangers of its influence on migration legislation in Europe" Studies in Ethnicity and Nationalism Vol. 10, No. 2 pg 234-254.

3. Basu, B., (2009), "Another look at mass migration and unions in western Europe" Economic Modelling Vol. 26, No. 5 pg 878-885.

4. Bloemraad, I. Korteweg, A. Yurdakul, G., (2008), "Citizenship and immigration: multiculturalism, assimilation, and challenges to the nation-state" Annual Review of Sociology Vol. 34, No. 1 pg 153179.

5. Bryman, A., (2012), "Social research methods", Oxford: Oxford University Press, 4th Edition.

6. Castles, S. Miller, M., (2009), "The age of migration: international population movements in the modern world" New York: Guilford Press, 4th Edition.
7. Ceccorulli, M., (2009), "Migration as a security threat: internal and external dynamics in the European Union" Forum on the Problems of Peace and War, Florence Working Paper No: 65/09 pg 1-30.

8. Damelang, A. Haas, A., (2012), "the benefits of migration: cultural diversity and labour market success" European Societies Vol. 14, No. 3 pg 362392.

9. Doyle, M., (2004), "the challenge of worldwide migration" Journal of International Affairs Vol. 57, No. 2 pg 1-5.

10. Held, D. McGrew, A. Goldblatt, D. Perraton, J., (1999), "Global Transformations: Politics, Economics and Culture", Cambridge: Polity Press.

11. Heywood, A., (2011), "Global Politics”, Basingstoke: Palgrave Macmillan.

12. Hijzen, A. Wright, P., (2010), "Migration, trade and wages" Journal of Population Economics Vol. 23, No. 4 pg 1189-1211.

13. Ivlevs, A. King, R., (2012), "Family migration capital and migration intentions" Journal of family and economicissues Vol. 33, No. 1 pg 118-129.

14. Kosar, K., (2007), "International Migration A Very Short Introduction”, New York: Oxford University Press.

15. Kymlicka, W., (2010), "The rise and fall of multiculturalism? New debates on inclusion and accommodation in diverse societies", in S. Vertovec, and S. Wessendorf (eds) The Multiculturalism Backlash, Abingdon: Routledge, pg 32-49.

16. Kymlicka, W., (2011), "Multicultural citizenship within multination states" Ethnicities, Vol. 11, No. 3 pg 281-302.

17. Lentin, A., (2005), "Replacing 'race', historicizing 'culture' in multiculturalism" Patterns of Prejudice, Vol. 39, No. 4 pg 379-396.

18. McKinstry, L. (2013) Mass Immigration is Destroying Our Once Great Nation. [Online]. Available from: https://www.express.co.uk/comment/columnists/leomckinstry/451080/Mass-immigration-is-destroyingour-once-great-nation, [accessed 28th September 2019]

19. Modood, T. Ahmad, F., (2007), "British muslim perspectives on multiculturalism" Theory, Culture \& Society, Vol. 24, No. 2 pg 187-213.

20. Niebuhr, A., (2010), "Migration and innovation: does cultural diversity matter for regional R\&D activity?" Papers in Regional Science, Vol. 89, No. 3 pg 563585. 
21. Orcalli, G., (2007), "Constitutional choice and European immigration policy" Constitutional Political Economy, Vol. 18, No. 1 pg 1-20.

22. Papademetriou, D., (1997), "Migration" Foreign Policy, Vol. 109, pg 15-31.

23. Polgreen, L. Simpson, N., (2011), "Happiness and international migration" Journal of Happiness Studies, Vol. 12, No. 5 pg 819-840.

24. Schmidt, C. Stilz, A. Zimmermann, K., (1994), "Mass migration, unions, and government intervention" Journal of Public Economics, Vol. 55 No. 2 pg 185201.

25. Seglow, J., (2005), "The ethics of immigration" Political Studies Review, Vol. 3 No. 3 pg 317-334.

26. Steiner, N., (2009), "International migration and citizenship today”, Abingdon: Routledge.

27. Tanrisever, O., (2007), "Review of International Migration and Security: Opportunities and Challengesby Elspeth Guild and Joanne van Selm. Comparative Sociology Vol. 6, pg 232-245.

28. Vertovec, S. Wessendorf, S., (2010), "Introduction: Assessing the backlash against multiculturalism in Europe" in S. Vertovec, and S. Wessendorf (eds) The Multiculturalism Backlash, Abingdon: Routledge, pg 1-31. 